\title{
Pelatihan Creative Design Thinking Start Up Entrepreneur Dikalangan Siswa Kelas XII SMK Industri Kreatif Kota Bandar Lampung
}

\author{
Arif Sugiono*, Suripto, Supriyanto \\ Ilmu Administrasi Bisnis, Universitas Lampung, Bandar Lampung, 35145, Lampung, Indonesia
}

\begin{abstract}
Abstrak.
SMK Industri Kreatif (Dahulu SMKN 5 Bandar Lampung), setiap tahunnya meluluskan tenaga terampil di bidang industri kreatif, khususnya sub sektor kriya. Namun, pada umumnya, setelah lulus para lulusannya masih berorientasi pada job seeker, dan mengalami kegagalan pada saat memulai sebuah usaha. Di sisi lain, jumlah start up entrepreneur di bidang Industri Kreatif di Indonesia pada umumnya, dan Kota Bandar Lampung pada khususnya masih kekurangan. Berangkat dari kondisi tersebut, maka pelatihan tentang start up entrepreneur dan design thinking dalam memulai bisnis menjadi penting dan relevan untuk dilakukan di SMK Industri Kreatif, khususnya siswa kelas XII. Metode yang digunakan adalah diskusi, ceramah dan membahas kasus-kasus yang menarik, tentang start up entrepreneur. Dengan diadakannya pelatihan ini, diharapkan akan terbentuk motivasi yang kuat untuk menjadi seorang yang merintis sebuah bisnis baru / startup entrepreneur; pemahaman design thinking yang baik dan benar tentang bagaimana mendirikan dan menjadi start up entrepreneur di industri kreatif dan mendesain model bisnis start up yang baik. Setelah dilakukan kegiatan pengabdian dengan metode diatas, hasil pre-test dan post-test menunjukkan adanya peningkatan pemahaman peserta pelatihan tentang materi pelatihan.
\end{abstract}

Kata kunci.

Start Up Entrepreneur, Design Thinking, Industri Kreatif.

\section{PENDAHULUAN}

Dinamika lingkungan makro di bidang teknologi informasi, kondisi sosial, budaya, ekonomi, politik dan kompetisi global yang semakin dinamis menuntut kita sebagai bangsa harus melakukan transformasi ekonomi, dari aktivitas ekonomi yang berbasis sumber daya alam (primer), menuju ke arah ekonomi yang mempunyai nilai tambah yang berbasis pengetahuan, teknologi, ide dan kreativitas. Industri yang relevan dalam merespon transformasi ekonomi tersebut, adalah industri kreatif. Karena industri kreatif adalah satusatunya industri yang berorientasi nilai tambah yang berbasiskan ide, ilmu pengetahuan yang lahir dari kreativitas sumber daya manusia [1,2].

Pada perkembangannya, Industri kreatif, hadir sebagai gelombang ekonomi baru, dan

* Corresponding author: arif.sugiono@fisip.unila.ac.id

Received 18 November 2020; Received in revised form 28 November 2020; Accepted 9 December 2020 Available online 24 December 2020

Lembaga Penelitian dan Pengabdian Kepada Masyarakat

Universitas Lampung 
merupakan emerging industry/industri yang sedang tumbuh di berbagai negara, tanpa terkecuali Indonesia. Banyak negara sudah mengambil berbagai langkah akselarasi, guna meningkatkan peran industri kreatif dalam perekonomian negara. Sehingga, kontribusi industri kreatif (penyerapan tenaga kerja, sumbangan PDB, dII) diberbagai negara, semakin meningkat, lihat Tabel 1.

Tabel 1. Kontribusi Industri Kreatif di Beberapa Negara [3]

\begin{tabular}{clcc}
\hline \multirow{2}{*}{ No } & \multicolumn{1}{c}{ Negara } & \multicolumn{2}{c}{ Kontribusi Industri Kreatif } \\
\cline { 2 - 4 } & PDB & Tenaga Kerja \\
\hline 1 & Australia Serikat & $11,5 \%$ & $8,51 \%$ \\
2 & Korea Selatan & $10,3 \%$ & $8 \%$ \\
3 & $9,89 \%$ & $6,24 \%$ \\
4 & Hungaria & $7,42 \%$ & $7,28 \%$ \\
5 & RRT & $6,37 \%$ & $6,52 \%$ \\
6 & Panama & $6,35 \%$ & $3,17 \%$ \\
7 & Malaysia & $5,70 \%$ & $7,50 \%$ \\
8 & Filipina & $9,89 \%$ & $6,24 \%$ \\
9 & Meksiko & $4,77 \%$ & $11,01 \%$ \\
10 & Kroasia & $7,42 \%$ & $7,28 \%$ \\
11 & Indonesia & $4,11 \%$ & $3,75 \%$ \\
12 & Afrika Selatan & $4,1 \%$ & $4,08 \%$ \\
13 & Kolumbia & $3,3 \%$ & $5,8 \%$ \\
14 & Ukraina & $2,85 \%$ & $3,90 \%$ \\
15 & Peru & $4,1 \%$ & $4,08 \%$ \\
\hline
\end{tabular}

Khusus di Indonesia, Di tengah usaha penguatan industri kreatif, kontribusi industri ini menunjukkan angka yang menggembirakan. Berdasarkan data dari Kementerian Pariwisata dan Ekonomi Kreatif [2], dan hasil survei ekonomi kreatif, hasil kerja sama BEKRAF RI dan BPS [4], menunjukkan selama 4 (empat) tahun terakhir (2012 sampai 2016), kontribusi ekonomi kreatif, menunjukkan kecenderungan yang meningkat. Pada tahun 2010-2013, nilai PDB Atas Dasar Harga Berlaku (ADHB), ekonomi kreatif rata-rata sebesar Rp. 555 triliun dengan kontribusi rata-rata 7,1 \% terhadap PDB nasional. Pada tahun 2010, industri kreatif berkontribusi sebesar Rp. 473 triliun.

Selanjutnya, pada tahun 2012 meningkat menjadi Rp.573,89 triliun atau setara 6,9\% terhadap Produk Domestik Bruto (PDB). Karena pada tahun 2013 terjadi krisis/pelambatan ekonomi global, kontribusi industri kreatif mengalami penurunan, sehingga kontribusi industri kreatif terhadap PDB menjadi Rp.486,1 triliun. Besarnya kontribusi tersebut, menjadikan industri kreatif berada di atas sektor ekonomi utama keuangan, real estate, dan jasa perusahaan; pengangkutan dan komunikasi; dan Listrik, Gas.

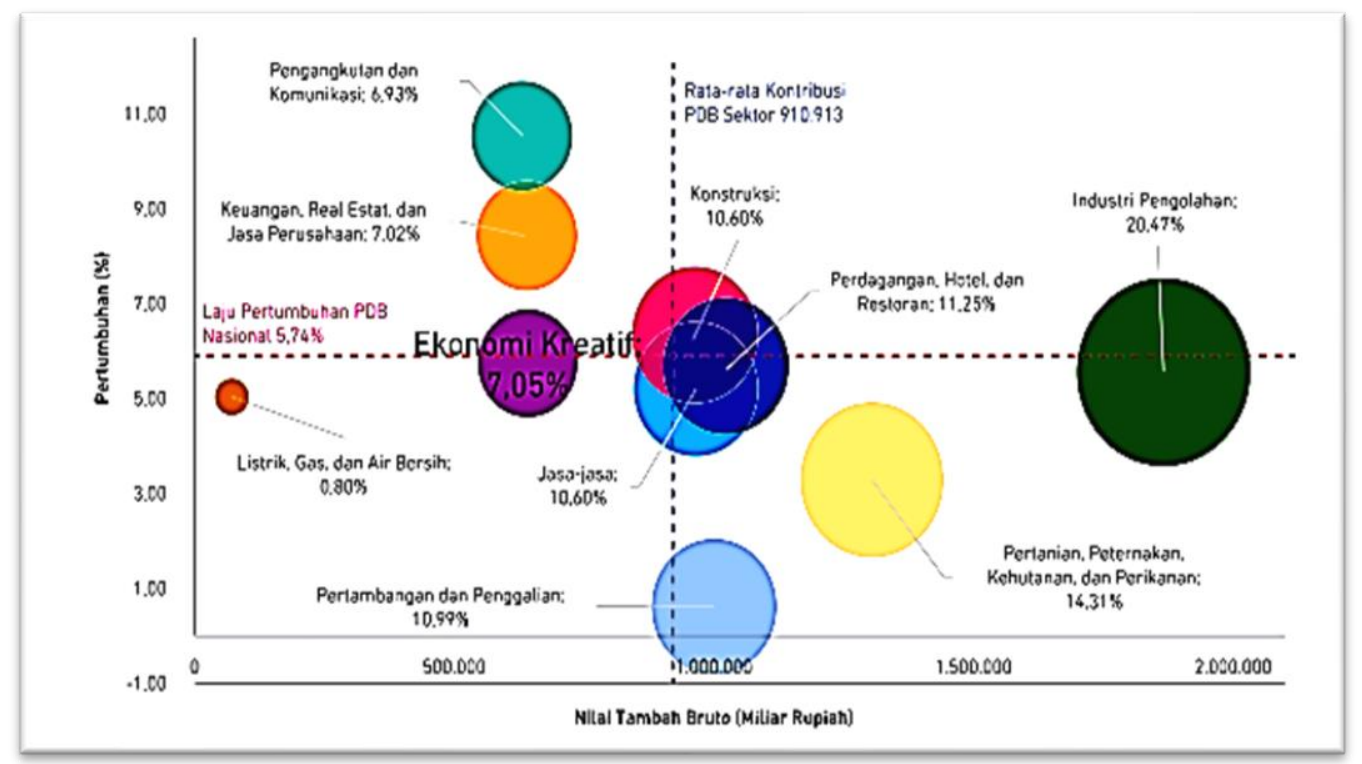

Gambar 1. Pertumbuhan, Nilai Tambah Bruto dan Kontribusi Sektor Ekonomi (2013) [4]. 
Pada dimensi empiris, agenda transformasi ekonomi dan penguatan peran dan kontribusi industri kreatif di Indonesia masih menemukan berbagai kendala pada berbagai level, baik pada level makro, meso dan mikro [5-7]. Selanjutnya, Sugiono mengidentifikasi beberapa hambatan pada level mikro/pelaku usaha, diantaranya yang paling dominan adalah belum meratanya kualitas sumber daya manusia/SDM yang masih minim, sehingga belum memungkinkan terbangunnya sebuah mindset start up entrepreneur yang baik dan benar, minimnya kreativitas, ide sehingga belum bisa menciptakan model bisnis yang diterima pasar dengan baik,aAtau dengan kata lain, sustainability competitive advantage yang rendah [3]. Belum meratanya kualitas SDM dan berbagai permasalahan diatas, menjadikan pelaku start up entrepreneur yang mampu berkontribusi terhadap perekonomian daerah/nasional masih didominasi di sebagian kecil wilayah yang ada di Pulau Jawa.

Sedangkan perkembangan dan kontribusi industri kreatif di wilayah luar Pulau Jawa (khususnya Kota Bandar Lampung), masih belum berkontribusi secara significant [4]. Sementara itu, SMK Kreatif Bandar Lampung adalah satu-satunya SMK yang bergerak di bidang industri kreatif, dengan fokus menyiapkan SDM yang kratif di berbagai sub sektor industri kreatif. Atas dasar itulah kegiatan pengabdian dilaksanakan.

\section{METODE}

Proses dilakukan dengan pembelajaran kelas dengan menggunakan metode blended learning, yakni pembelajaran yang menggabungkan berbagai cara penyampaian, model pengajaran, dan gaya pembelajaran, memperkenalkan berbagai pilihan media dialog antara fasilitator dengan orang yang mendapat pengajaran. Blended learning juga sebagai sebuah kombinasi pengajaran langsung (face-to-face) dan pengajaran online, tapi lebih daripada itu sebagai elemen dari interaksi sosial. Untuk metode face to face, bentuk pelaksanaan kegiatan adalah ceramah, diskusi, pembahasan kasus-kasus dan tanya jawab. Sedangkan metode online, adalah mengakses video dari berbagai sumber yang relevan, memebentuk komunitas on line lewat media sosial (WAG) sehingga memungkinkan untuk terus berinteraksi dan diskusi tentang tema-tema yang terkait dengan materi pelatihan, dan industri kreatif.

Tabel 2. Prosedur Kerja

\begin{tabular}{|c|c|c|c|}
\hline No. & Kegiatan & Person In Charge & Keterangan \\
\hline 1 & Pretest & Tim Pengabdian & $\begin{array}{l}\text { Peserta akan dibagikan serangkaian } \\
\text { pertanyaan yang bertujuan untuk } \\
\text { mengetahui sejauh mana tingkat } \\
\text { pemahaman peserta tentang } \\
\text { Start up entrepreneur dan design } \\
\text { thinking dalam memulai start up } \\
\text { entrepreneur }\end{array}$ \\
\hline 2 & $\begin{array}{l}\text { Ceramah/Penyampaian } \\
\text { Materi }\end{array}$ & $\begin{array}{l}\text { Dr. Arif Sugiono } \\
\text { Dr. Suripto } \\
\text { Supriyanto, M.Si }\end{array}$ & $\begin{array}{l}\text { Memberikan pemahaman tentang start } \\
\text { up entrepreneur dan creative design } \\
\text { thinking dalam memulai start up } \\
\text { entrepreneur }\end{array}$ \\
\hline 3 & Post-test & Tim Pengabdian & $\begin{array}{l}\text { Peserta akan dibagikan serangkaian } \\
\text { pertanyaan yang bertujuan untuk } \\
\text { mengukur sejauh mana tingkat } \\
\text { pemahaman peserta tentang materi } \\
\text { yang telah disampaikan. }\end{array}$ \\
\hline
\end{tabular}

Adapun pihak-pihak yang terlibat di dalam kegiatan ini ialah tim pengabdian dari jurusan IImu Administrasi Bisnis FISIP Universitas lampung dengan pihak sekolah, yang meliputi (Kepala Sekolah, Guru dan Siswa Kelas XII). Evaluasi kegiatan akan dilakukan dengan mengukur tingkat pemahaman peserta terkait start up entrepreneur dan creative design thinking. Keberlanjutan program adalah manifestasi blended learning, dengan mengedepankan pola diskusi online dengan membentuk komunitas, selanjutnya akan difasilitasi dalam program inkubasi bisnis yang dilakukan oleh Laboratorium Bisnis, jurusan Ilmu Administrasi Bisnis. 


\section{HASIL DAN PEMBAHASAN}

\section{Pemahaman Awal Peserta Sebelum Pelatihan}

Kegiatan pelatihan ini diikuti oleh siswa kelas XII SMK Indsutri Kreatif yang berjumlah 23 orang (absensi peserta terlampir), dengan tetap menerapkan protokol covid-19 (sebagaimana dapat di lihat pada foto-foto kegiatan / dokumentasi selama kegiatan). Untuk mengetahui perubahan pemahaman peserta akan materi pelatihan, khususnya pemahaman awal, dilakukan pre-test yang berbentuk pilihan benar dan salah. Jumlah pretest sebanyak 10 (sepuluh) pertanyaan dan dikerjakan selama sepuluh menit (soal pre-test terlampir). Materi pre-test merupakan rangkuman dari materi yang akan disampaikan dalam pelatihan. Kriteria hasil pre-test yang digunakan adalah sebagai berikut: (hasil pre-test dapat dilihat pada tabel pre-test).

a. $0 \%-49,9 \%$ : Belum Memahami

b. $50 \%-74,9 \%$ : Cukup Memahami

c. $75 \%-100 \%$ : Sangat Memahami

Berdasarkan hasil pre-test pada tabel dibawah diketahui bahwa rata-rata tingkat pemahaman awal peserta adalah 34,34\%. Hal ini berarti seluruh peserta masuk dalam kriteria belum memahami tentang materi pelatihan, yakni tentang design thinking. Ketidakpahaman para siswa kelas XII SMK Industri Kreatif, bisa dimaklumi karena kurikulum pembelajaran, terutama mata pelajaran tentang kewirausahaan belum membahas tentang design thinking dalam memulai menjadi seorang technopreneur.Lebih jelas, tentang detail pemahaman awal peserta pelatihan dapat dilihat dalam tabel 3.

Tabel 3. Hasil Pre dan Post-test

\begin{tabular}{clccc}
\hline No. & \multicolumn{1}{c}{ Nama Peserta } & $\begin{array}{c}\text { Jumlah } \\
\text { Jawaban } \\
\text { Benar } \\
\text { (Pre-Test) }\end{array}$ & $\begin{array}{c}\text { Jumlah } \\
\text { Jawaban } \\
\text { Benar } \\
\text { (Post-Test) }\end{array}$ & $\begin{array}{c}\text { Tingkat Pemahaman } \\
\text { Akhir Peserta (\%) }\end{array}$ \\
\hline 1. & Lusi Efrilia Rahma & 4 & 7 & 70 \\
2. & Rasya Ferdalita & 4 & 8 & 80 \\
3. & Nanda Aulia & 3 & 8 & 80 \\
4. & Riska Oktavia & 4 & 7 & 70 \\
5. & Ryan Fauziah & 4 & 9 & 100 \\
6. & Ferdenan Julio Nendy & 3 & 10 & 80 \\
7. & Abdul Arif P & 2 & 8 & 80 \\
8. & M. Fadly Asmansharin & 2 & 8 & 90 \\
9. & Anisa Rahmawati & 3 & 9 & 70 \\
10. & Pendi Pratama & 3 & 7 & 80 \\
11. & Daffa RDG & 4 & 8 & 90 \\
12. & Asep Saipudin & 4 & 7 & 100 \\
13. & Uswatun Khasanah & 4 & 9 & 70 \\
14. & Uswatun Nisa & 4 & 10 & 80 \\
15. & Dyah Ayu Dwi PS & 4 & 7 & 90 \\
16. & Muhammad Azri Basri & 4 & 8 & 100 \\
17. & JP Fadellah & 4 & 9 & 90 \\
18. & Irfan Fadhil & 4 & 8 & 80 \\
19. & Wanda Ramadhori & 4 & 10 & 90 \\
20. & Sekar Iman & 3 & 9 & 100 \\
21 & lkhsan Hanif N & 2 & 8 & $\mathbf{8 3} \%$ \\
22 & Maulana Rafi & 3 & 9 & \\
23 & Siti Habsoh & 3 & 10 & \\
\hline \multicolumn{7}{l}{ Rata-Rata } & $\mathbf{3 , 4}$ & $\mathbf{8 , 3 0}$ & \\
\hline
\end{tabular}

Berdasarkan hasil post-test pada tabel diatas diketahui bahwa rata-rata tingkat pemahaman akhir peserta adalah $83 \%$. Nilai ini masuk dalam kriteria sangat memahami. Jika dibandingkan dengan hasil pre-test berarti secara rata-rata telah terjadi peningkatan pemahaman peserta tentang tentang materi pelatihan. Bahkan ada beberapa peserta (4 peserta), dalam pre-test ini, mampu menjawab dengan benar semua soal. Selanjutnya, dari 23 peserta, terdapat 6 peserta yang mampu mengerjakan dengan hanya 1 (satu) soal yang salah dari jumlah total soal yang diberikan. Nilai terendah dalam post-test ini berada pada 
angka 7 (tujuh), yang dicapai oleh 6 (enam) peserta pelatihan. Sehingga 5 (lima) siswa lainnya mendapat nilai 8 (delapan).

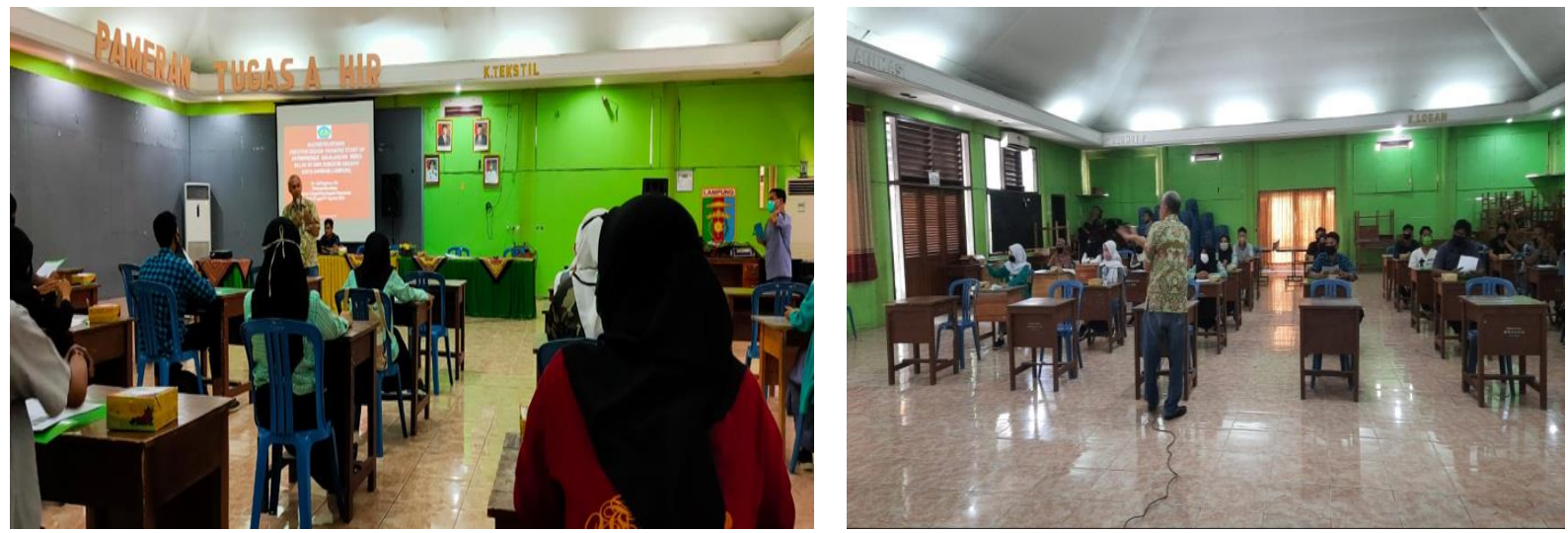

Gambar 2. Foto Penyampaian Materi.

Sebaran nilai yang cukup mengembirakan tersebut, dapat diartikan bahwa hampir semua peserta, sangat memahami materi pelatihan. Dengan pemahaman yang sangat memahami, maka berbekal design thingking yang benar, diharapkan jaminan keberhasilan peserta dalam memulai dan menjalankan start up akan semakin besar. Selain itu, peserta yang pada umumnya sebagai generasi muda, akan lebih yakin dalam memilih dan menekuni profesi dan memulai menjadi entrepreneur.

\section{KESIMPULAN}

Berdasarkan informasi yang didapatkan dilapangan selama pelaksanaan kegiatan pengabdian masyarakat, maka dapat disimpulkan beberapa hal diantaranya:

1. Minat, motivasi generasi muda untuk menjadi entrepreneur, masih belum terlalu kuat, sehingga perlu upaya dari berbagai pihak untuk terus aktif berkolaborasi dengan berbagai pihak untuk membangun kesadaran kolektif bagi semua kalangan (terutama generasi muda) akan penting dan prospektif yang bagus terhadap profesi entrepereneur.

2. Peningkatan pemahaman peserta pelatihan cukup mengembirakan. berdasarkan pretest dan post-test, menunjukkan bahwa pemahaman awal peserta berada pada kategori belum memahami, sedangkan setelah dilakukan pengabdian, menunjukkan angka sangat memahami.

\section{DAFTAR PUSTAKA}

[1] Howkins, John. 2009. The Creative Ecologies: Where Thinking is a Proper Job. University of Quensland Press.

[2] Kemenparekraf RI. 2014. Ekonomi Kreatif: Kekuatan Baru Indonesia menuju 2025. Kementerian Pariwisata dan Ekonomi Kreatif Republik Indonesia.

[3] Sugiono, Arif, Ria A, Sam'un JR, Erna M. 2018. Dynamic Capabilities: Strategi dan Kunci Sukses Persaingan dalam Bidang Industri Kreatif. Yogjakarta: Penerbit Ombak.

[4] BPS RI. 2018. Data Statistik dan Hasil Survei Ekonomi Kreatif. Badan Pusat Statistik Republik Indonesia dan Badan Ekonomi Kreatif Republik Indonesia.

[5] Nee, Victor. 2003. The New Institutionalism in Economic and Sociology. Center of Study Economy and Society. Vol.4.November 2003.

[6] Sugiono, Arif \& Kurnianing Isololipu, 2010. Berani Hidup Kaya: Jurus Jitu Menjadi Entrepreneural Handal. Pustaka Timur. Yogjakarta.

[7] Fitriani, Rachma. 2015. Menguak Daya Saing UMKM Industri Kreatif: Sebuah Riset Tindakan Berbasis Soft System Methodology. Yayasan Obor Indonesia. 